Etnolingual Vol 2 No 2

November, 2018, 165-176

\title{
TINDAK TUTUR DALAM PIDATO PASRAH TINAMPI PERNIKAHAN MASYARAKAT JAWA: SEBUAH KAJIAN SOSIOPRAGMATIK
}

\author{
Fadhila Kusumaningrum \\ fadhilakusumaningrum@gmail.com \\ Universitas Airlangga
}

\begin{abstract}
Marriage is a sacred event involving two families both from the groom and bride who sometimes have different cultural backgrounds. This can affect how the marriage will be carried out. This research was carried out in Javanese community wedding speeches, especially in the pasrah tinampi procession. The data was obtained from the documentation of the marriage ceremony of one of the Javanese people. The researcher used a qualitative descriptive method by analyzing and explaining the data obtained. This study aims to see how speech acts appear in Javanese marriage speeches. From this study, five categories of speech acts based on Searle (1979) were found, namely declarative, representative, expressive, directive and commissive, which spoken utterances had a contextual function.
\end{abstract}

Keywords : wedding speech, sociopragmatics, speech acts

\begin{abstract}
Abstrak
Pernikahan merupakan suatu peristiwa sakral yang melibatkan dua keluarga baik dari pihak mempelai laki-laki maupun mempelai perempuan yang terkadang memiliki latar belakang budaya yang berbeda. Hal tersebut bisa saja mempengaruhi bagaimana pernikahan tersebut akan dilakukan. Penelitian ini dilakukan pada pidato pernikahan masyarakat Jawa terutama pada prosesi pasrah tinampi. Data diperoleh dari video dokumentasi pernikahan salah satu masyarakat Jawa. Peneliti menggunakan metode deskriptif kualitatif dengan cara menganalisis dan menjelaskan data yang diperoleh. Penelitian ini bertujuan untuk melihat bagaimana tindak tutur yang muncul pada pidato pernikahan masyarakat Jawa. Dari penelitian ini, penulis menemukan lima kategori tindak tutur berdasarkan Searle (1979), yaitu deklaratif, representatif, ekspresif, direktif dan komisif, yangmana tuturan yang diucapkan memiliki fungsi sesuai konteks.
\end{abstract}

Kata kunci : pidato pernikahan, sosiopragmatik, tindak tutur

\section{PENDAHULUAN}

\section{Latar Belakang}

Komunikasi dalam kehidupan sehari-hari tidak terlepas dari pengaruh latar belakang budaya maupun sosial baik dari penutur maupun mitra tutur. Pemilihan cara berkomunikasi tergantung pada berbagai faktor yang meliputi usia, pekerjaan, tingkat sosial, latar, dan fungsi-fungsi sosial lainnya. Sebuah komunitas budaya akan menggunakan bahasa yang dimiliki oleh komunitasnya. Selain digunakan sebagai bahasa komunikasi sehari-hari, bahasa tersebut juga digunakan pada acara adat maupun keagamaan yang masih terkait dengan budaya tersebut. Firt (dalam 
Wijana, 1996:5) mengemukakan bahwa kajian bahasa tidak dapat dipisahkan tanpa mempertimbangkan konteks situasi tutur. Konteks situasi tutur tersebut meliputi partisipasi, tindakan partisipasi (baik tindak verbal maupun nonverbal), ciri-ciri situasi lain yang relevan dengan hal yang sedang berlangsung, dan dampak-dampak tindakan tutur yang diwujudkan dengan bentuk-bentuk perubahan yang timbul akibat tindakan partisipan.

Dalam sebuah tuturan, tentu terdapat maksud-maksud dan tujuan dari penutur kepada mitra tutur. Salah satunya adalah maksud untuk melakukan suatu tindakan yang disebut dengan tindak tutur. Tindak tutur memiliki fungsi yang berbeda-beda sesuai dengan konteksnya. Pidato merupakan salah satu tuturan tidak langsung yang mengandung pesan-pesan tertentu. Jenis pidato bermacam-macam, biasanya disesuaikan dengan jenis atau tema acara. Penelitian ini akan menganalisis pidato dalam acara pernikahan, khususnya pada prosesi pasrah tinampi yang dilakukan oleh masyarakat Jawa. Pasrah tinampi merupakan sebuah prosesi yang dilakukan untuk menerima mempelai laki-laki oleh keluarga mempelai perempuan setelah acara akad nikah. Prosesi ini dilakukan dengan memberikan pidato baik dari pihak mempelai lakilaki maupun pihak perempuan melalui perwakilan dari masing-masing keluarga.

Tujuan penelitian ini adalah untuk mengetahui tindak tutur yang terdapat dalam pidato pernikahan yang disampaikan oleh masing-masing perwakilan keluarga. Penelitian ini menggunakan pendekatan teori tindak tutur milik Searle. Searle membagi tindak tutur ke dalam lima fungsi yaitu deklaratif, representatif, ekspresif, direktif dan komisif. Penelitian ini diharapkan memiliki kontribusi dalam kajian pragmatik dan penelitian-penelitian berikutnya, terutama dalam tindak tutur yang berkaitan dengan latar belakang penutur dan budayanya. Serta, melalui tindak tutur tersebut, pengguna tuturan mampu mempelajari dan memahami tindak tutur budaya tertentu, terutama pada komunikasi lisan.

\section{TINJAUAN PUSTAKA}

\section{Perkawinan dalam Adat Jawa}

Pernikahan adalah sebuah ikatan lahir dan batin antara seorang laki-laki dan perempuan untuk hidup bersama dan membentuk sebuah keluarga. Menurut Undang undang No. 1 Tahun 1974 "Perkawinan adalah ikatan lahir batin antara seorang pria dan seorang wanita sebagai suami dan istri dengan tujuan membentuk keluarga (rumah tangga) yang bahagia dan kekal berdasarkan Ketuhanan Yang Maha Esa” (Saleh, 1976). Upacara pernikahan adat Jawa meliputi, akad nikah, upacara panggih, dan resepsi. Dalam setiap acara tersebut, terdiri dari berbagai prosesi di dalamnya. Selain sekian prosesi yang telah disebutkan di atas, terdapat sebuah prosesi yang bernama pasrah tinampi. Pasrah tinampi merupakan sebuah prosesi yang dilakukan untuk menerima mempelai laki-laki oleh keluarga mempelai perempuan setelah acara akad 
nikah. Prosesi ini dilakukan dengan memberikan pidato baik dari pihak mempelai lakilaki maupun pihak perempuan melalui perwakilan dari masing-masing keluarga.

\section{Tindak Tutur}

Tindak tutur diartikan bagaimana seseorang melakukan tindakan sekaligus tuturan kepada orang lain. Tindak tutur merupakan linguistik performansi yang termasuk dalam kajian pragmatik yang berfokus terhadap kajian mengenai makna yang terdapat dalam sebuah tuturan. Tindak tutur ialah melakukan tindakan tertentu melalui kata misalnya, menolak (tawaran, permohonan), berterima kasih, memberi salam, memuji, minta maaf, berjanji dan mengeluh. Bentuk tindak tutur bisa saja berbeda antar satu budaya dan budaya lain. Misalnya, dalam kebudayaan tertentu menolak (tawaran, permohonan) dapat dilakukan secara langsung, sementara dalam kebudayaan lainnya dilakukan harus dengan basa-basi tertentu sebelum penolakan diucapkan atau bahkan tanpa diucapkan sama sekali. Hal ini menyebabkan terjadinya kesalahpahaman terhadap maksud ucapan penutur.

Chaer (2010:61) menjelaskan bahwa tindak tutur adalah berlangsungnya interaksi linguistik dalam satu bentuk ujaran atau lebih yang melibatkan dua pihak, yaitu penutur atau lawan tutur dengan satu pokok tuturan dalam waktu, tempat, dan situasi tertentu. Dalam suatu tuturan, penutur biasanya berharap maksud komunikatifnya akan dimengerti oleh pendengar/lawan tutur.

\section{Tipe-tipe Tindak Tutur}

Austin dalam Wardaugh $(2015: 251)$ membagi tindak tutur menjadi tiga, yaitu lokusi, ilokusi, dan perlokusi. Tindak tutur lokusi adalah tindak tutur yang digunakan untuk menyatakan sesuatu. Kalimat "Disini dingin" merupakan sebuah lokusi yang memiliki maksud agar si mitra tutur berkenan mengambilkan jaket atau menutup pintu. Kemudian, maksud dari pernyataan "Disini dingin" disebut sebagai ilokusi. Austin mendefinisikan ilokusi sebagai "performance of act in saying something". Kekuatan ilokusi terletak pada maksud dari penutur misalnya penyampaian informasi, perintah, dan peringatan. Seperti yang telah disebutkan diatas bahwa penutur tidak hanya sekedar mengatakan bahwa "Disini dingin", melainkan adanya keinginan agar mitra tutur memberikannya jaket atau menutup pintu. Sedangkan, jika tuturan yang diucapkan penutur memberi dampak atau pengaruh terhadap perilaku mitra tuturnya, maka tindak tutur tersebut disebut dengan perlokusi.

Dalam Yule (1996), Searle (1979) mengkasifikasi tindak tutur ilokusi dalam beberapa jenis yaitu, deklaratif(declarations), representatif(representatives), ekspresif (expressives), direktif (directives), dan komisif (commisives). 
Tabel 1. Klasifikasi Tindak Tutur

\begin{tabular}{l|l|l}
\hline Jenis Tindak Tutur & Kesesuaian Tuturan & $\mathbf{P}=$ Penutur \\
\hline Deklarasi & Kata-kata mengubah dunia & Situasi \\
Representatif & Membuat kata-kata sesuai dengan dunia & P meyakini S \\
Ekspresif & Membuat kata-kata sesuai dengan dunia & P merasakan S \\
Direktif & Membuat dunia sesuai dengan kata-kata & P menginginkan S \\
Komisif & Membuat dunia sesuai dengan kata-kata & P bermaksud S \\
\hline
\end{tabular}

1) Deklaratif, yaitu tindak tutur yang dimaksudkan penuturnya untuk menciptakan hal (status, keadaan dsb) yang baru. Yule (1996:53) menyatakan bahwa tindak tutur deklaratif adalah jenis tindak tutur yang mengubah dunia melalui ucapan penutur dan mitra tutur, seperti memaafkan, menghukum, membatalkan, pemecatan dan pembaptisan. Misalnya pengucapan ijab qobul oleh calon mempelai pria yang menyebabkan statusnya berganti menjadi suami dan calon mempelai perempuan statusnya berganti menjadi seorang istri.

2) Representatif yaitu tuturan yang mengikat penuturnya akan kebenaran atas apa yang diujarkan. Tindak tutur jenis ini berupa pernyataan, ramalan, mengeluh, membanggakan, mengakui, memberi kesaksian dan menyarankan.

3) Ekspresif yaitu tindak tutur yang dimaksudkan penuturnya agar ujarannya diartikan sebagai evaluasi tentang hal yang disebutkan dalam tuturan itu seperti ucapan terima kasih, meminta maaf, dan ucapan selamat. Biasanya, kalimat ekspresif lebih mengacu pada hal yang sedang dirasakan oleh si penutur itu.

4) Direktif yaitu tindak tutur yang dimaksudkan penuturnya agar si pendengar melakukan tindakan yang disebutkan dalam tindakan itu seperti perintah, larangan, peringatan, mengusulkan, memohon, atau mendesak. Kalimat ini lebih mengacu pada keinginan penutur terhadap suatu hal atau situasi tertentu.

5) Komisif yaitu tindak tutur yang mengikat penuturnya untuk melaksanakan apa yang disebutkan di dalam tuturannya seperti berjanji, ancaman, tawaran, menyetujui, atau bersumpah. Tindak tutur ini menitikberatkan pada komitmen penutur terhadap tindakannya di masa yang akan datang.

\section{METODE}

Dalam penelitian ini, penulis menggunakan metode deskriptif kualitatif. Metode deskriptif yang dipilih karena penelitian yang dilakukan bertujuan untuk menggambarkan dengan jelas tentang objek yang diteliti secara alamiah (Djajasudarma 
1993: 8-9). Surakhmad (1978: 739) menyebutkan bahwa penelitian deskriptif merupakan penelitian yang mencoba menggambarkan dan menganalisis data mulai dari tahap pengumpulan data, penyusunan data dan analisis interpretasi terhadap data. Sedangkan, kualitatif digunakan karena penelitian ini tidak melibatkan perhitungan secara statistik. Data diperoleh dari video pernikahan salah satu masyarakat Jawa yang dilakukan beberapa bulan yang lalu. Data yang diperoleh kemudian ditulis ke dalam teks yang kemudian dianalisis untuk mengetahui tindak tutur yang terdapat dalam pidato tersebut. Terdapat dua buah pidato yang diteliti dalam penelitian ini, yaitu pidato dari pihak mempelai laki-laki dan pihak mempelai perempuan. Peneliti menggunakan metode deskriptif kualitatif yangmana penulis menganalisis dan menjelaskan data yang diperoleh. Dari penelitian ini, penulis menemukan lima kategori tindak tutur berdasarkan Searle (1979), yaitu deklaratif, representatif, ekspresif, direktif dan komisif, yangmana tuturan yang diucapkan memiliki fungsi sesuai konteks.

\section{HASIL DAN PEMBAHASAN}

Bagian ini berisi tentang pembahasan dan analisis data. Seperti yang disebutkan sebelumnya bahwa Pragmatik merupakan kajian yang meneliti tuturan berdasarkan konteks yang meliputi situasi (tempat dan waktu) serta partisipan. Pidato tersebut disampaikan dalam acara pernikahan, khususnya pada prosesi pasrah tinampi yang merupakan prosesi diserahkannya mempelai pria melalui keluarganya kepada keluarga mempelai perempuan. Partisipan yang terlibat dalam acara ini sebagian besar merupakan pihak keluarga dari kedua mempelai dan beberapa tamu undangan yangmana sebagian besar memiliki latar belakang budaya Jawa. Sehingga, bahasa yang digunakan dalam pidato ini sebagian besar adalah bahasa Jawa. Karena acara tersebut merupakan acara formal, maka bahasa Jawa yang digunakan adalah Bahasa Jawa Krama Inggil dan kadang-kadang Krama Madya. Analisis data pada bahasan kali ini disajikan dalam bentuk tabel seperti berikut :

\section{Tindak tutur yang terdapat dalam pidato yang disampaikan oleh pihak mempelai laki-laki}

Dalam pidato yang disampaikan oleh pihak mempelai laki-laki, ditemukan lima kategori tindak tutur yaitu, deklaratif, representatif, direktif, dan ekspresif yang disajikan pada tabel-tabel berikut. 
Tabel 2. Deklaratif

\begin{tabular}{|c|c|c|}
\hline No & Tindak Tutur & Makna \\
\hline 1 & $\begin{array}{l}\text { Kulo pasrahaken kanthi X putro dalem nggih meniko kanthi } \\
\text { ucapan Bismillahirohmanirrohim, kulo pasrahaken dhateng } \\
\text { beliau yang terhormat Bapak E binti Ibu M sak keluargo. } \\
\text { Saya pasrahkan X, putra kami dengan ucapan } \\
\text { Bismillahhirohmanirrohim kepada yang terhormat Bapak Edan } \\
\text { Ibu M sekeluarga. }\end{array}$ & $\begin{array}{l}\text { Pihak keluarga } \\
\text { mempelai pria } \\
\text { menyerahkan mempelai } \\
\text { pria kepada pihak } \\
\text { keluarga mempelai } \\
\text { perempuan. }\end{array}$ \\
\hline
\end{tabular}

Tindak tutur deklaratif yang terdapat pada tabel diatas merupakan tindak tutur yang menyatakan bahwa mempelai laki-laki kini sudah menjadi bagian dari keluarga mempelai perempuan.

Tabel 2. Representatif

\begin{tabular}{|c|c|c|}
\hline No & Tindak Tutur & Makna \\
\hline 1 & $\begin{array}{l}\text { Mugi pikantuk rahmat lan ridhonipun Allah dados tiyang } \\
\text { ingkang mulyo lan katetapan iman fidhinyi waddunya wal } \\
\text { akhiroh. Allahuma aamiin. } \\
\text { Semoga mendapat rahmat dan ridho Allah SWT agar menjadi } \\
\text { manusia yang mulia dan diberi ketetapan iman, selamat dunia } \\
\text { akhirat. }\end{array}$ & $\begin{array}{l}\text { Pernyataan yang berisi } \\
\text { harapan agar senantiasa } \\
\text { diberkahi. }\end{array}$ \\
\hline 2 & $\begin{array}{l}\text { Mugi-mugiyo, Mas X tansah tanggungjawab penuh dhateng } \\
\text { keluarganipun detik meniko sak lajengipun. } \\
\text { Semoga, Mas X senantiasa bertanggungjawab penuh kepada } \\
\text { keluarganya mulai detik ini hingga selamanya. }\end{array}$ & $\begin{array}{l}\text { Pernyataan yang berisi } \\
\text { harapan agar senantiasa } \\
\text { diberkahi. }\end{array}$ \\
\hline 3 & $\begin{array}{l}\text { Pramilo, ojo sampe siro mbesuk nglakoni perjalanan anggonipun } \\
\text { bebrayan gawe sempit rupeke kebutuhan rumah tangga. } \\
\text { Oleh karena itu jangan sampai nanti dalam menjalankan } \\
\text { kehidupan berumahtangga, membuat sempit kebutuhan } \\
\text { rumahtangga. }\end{array}$ & $\begin{array}{l}\text { Pernyataan yang berupa } \\
\text { harapan mempelai } \\
\text { laki-laki mampu } \\
\text { bertanggungjawab pada } \\
\text { keluarganya. }\end{array}$ \\
\hline 4 & $\begin{array}{l}\text { Nek sampeyan iso ngadahi niku neng njero atine sampeyan, } \\
\text { sampeyan ngamalake saknjure neng tengah-tengahe bebrayan } \\
\text { panjennegan, insyaallah sampeyan dadi keluarga ingkang } \\
\text { tansah syukur marang arsane Allah. } \\
\text { Jika kamu bisa menempatkan itu dalam hatimu, kemudian } \\
\text { kamu mengamalkannya di tengah-tengah kehidupan kalian, } \\
\text { insyaallah kalian akan menjadi keluarga yang senantiasa } \\
\text { bersyukur pada Allah SWT. }\end{array}$ & $\begin{array}{l}\text { Nasihat/saran } \\
\text { untuk tidak saling } \\
\text { menyusahkan. }\end{array}$ \\
\hline
\end{tabular}




\begin{tabular}{|c|c|c|}
\hline 5 & $\begin{array}{l}\text { Wong syukur iku uayem, mas. Wong syukur, wong nrimo iku } \\
\text { ga ono beban. } \\
\text { Orang yang bersyukur itu tentram, mas. Orang yang bersyukur, } \\
\text { orang yang bisa menerima itu tidak ada beban. }\end{array}$ & $\begin{array}{l}\text { Nasihat/saran untuk } \\
\text { mengamalkan hal yang } \\
\text { baik. }\end{array}$ \\
\hline 6 & $\begin{array}{l}\text { Perbanyaklah lisan dan mulutmu untuk berdzikir, ingat sama } \\
\text { asma Allah. Insyaallah Allah akan membimbing dirimu. }\end{array}$ & $\begin{array}{l}\text { Pernyataan tentang } \\
\text { keadaan yang selalu } \\
\text { bersyukur. }\end{array}$ \\
\hline 7 & $\begin{array}{l}\text { Oleh karena itu, aku menyarankan saudara jadilah bapak dan } \\
\text { ibu rumah tangga yang baik, yang bisa mampu membimbing } \\
\text { punya keturunan, sehingga keturunanmu menjadi anak ingkang } \\
\text { sholeh dan sholehah, berbakti kepada dua orangtuanya dan } \\
\text { iman kepada Allah dan ajarannya. }\end{array}$ & $\begin{array}{l}\text { Nasihat/saran untuk } \\
\text { terus berdzikir. }\end{array}$ \\
\hline 8 & $\begin{array}{l}\text { Panjenengan, mas } \mathrm{X} \text { dan mbak } \mathrm{Y} \text {, saudara baru pertama ini } \\
\text { mengarungi dan mau menjalankan kehidupan yang baru. Oleh } \\
\text { karenanya rintangan dan tantangan tidak seperti ketika saudara } \\
\text { sendirian. Oleh karena itulah kesadaran dan tauhid saudara } \\
\text { harus diperkuat biarpun sampean jauh. }\end{array}$ & $\begin{array}{l}\text { Nasihat/saran untuk } \\
\text { menjadi suami dan istri } \\
\text { yang baik. }\end{array}$ \\
\hline 9 & $\begin{array}{l}\text { Namun kalau saudara memegang percaya, bahwa istrimu } \\
\text { melihat dirimu dan suami melihat dirimu, insyaallah itu akan } \\
\text { terjaga. }\end{array}$ & $\begin{array}{l}\text { Nasihat/saran untuk } \\
\text { memperkuat kesadaran } \\
\text { dan tauhid masing- } \\
\text { masing. }\end{array}$ \\
\hline 10 & $\begin{array}{l}\text { Namun, disatu sisi jika sampeyan sudah menanamkan rasa } \\
\text { kecemburuan, itu akan menjadi bencana di dalam tengah } \\
\text { keluarga. Oleh karenanya, rasa kesadaran dalam mengarungi } \\
\text { kehidupan harus kita hidupkan. Mustahil kita berkeluarga } \\
\text { tidak ada godaan dan rintangan. Namun jika diletakkan pada } \\
\text { kesadaran diri insyaallah itu akan mudah terselesaikan. }\end{array}$ & $\begin{array}{l}\text { Nasihat/saran untuk } \\
\text { saling percaya. } \\
\text { Nasihat/saran untuk } \\
\text { saling percaya dan } \\
\text { tidak mudah cemburu. }\end{array}$ \\
\hline
\end{tabular}

Tabel 2 menunjukkan bahwa tindak tutur yang digunakan dalam pidato dari pihak mempelai laki-laki mengandung tindak tutur representatif. Yang mana tindak tutur tresebut memiliki maksud untuk memberi saran, memberitahukan informasi. Saran-saran ini diberikan agar kelak baik mempelai laki-laki dan perempuan bisa menjalani kehidupan berumahtangga dengan baik.

Tabel 3. Direktif

\begin{tabular}{|l|l|l|}
\hline No & \multicolumn{1}{|c|}{ Tindak Tutur } & \multicolumn{1}{|c|}{ Makna } \\
\hline 1 & $\begin{array}{l}\text { Jangan mudah untuk berkata yang tidak baik di tengah } \\
\text { keluarga, dihadapan istri, dihadapan suami. }\end{array}$ & $\begin{array}{l}\text { Larangan untuk tidak berkata } \\
\text { tidak baik pada pasangan. }\end{array}$ \\
\hline
\end{tabular}




\begin{tabular}{|l|l|l|}
\hline 2 & $\begin{array}{l}\text { Jangan kotori hatimu dengan hati yang sirik, yang dendam, } \\
\text { yang egois, yang sok menang dhewe, sok pengen kuoso } \\
\text { dhewe di dalam tengah keluarga maupun sesamanya. }\end{array}$ & $\begin{array}{l}\text { Perintah untuk menjaga hati } \\
\text { dan dan kepercayaan pada } \\
\text { pasangan masing-masing. }\end{array}$ \\
$\begin{array}{l}\text { Seandainya sampeyan punya penghasilan besar, jangan } \\
\text { sampai anda menyisihkan penghasilan yang tidak diketahui } \\
\text { oleh istri. Oleh karena itu saya berpesan, isilah hatimu } \\
\text { dengan hati-hati yang positif, jangan suudzon dengan yang } \\
\text { belum nyata. Dengan itulah, saudara akan menjadi keluarga } \\
\text { yang baik, yang penuh ridho Allah. }\end{array}$ & \\
\hline 3 & $\begin{array}{l}\text { Jagalah dirimu baik dari sisi kesehatan, baik dari sisi } \\
\text { pendidikan dan jasadmu untuk melakukan rukuk, sujud, } \\
\text { lungguh dan salam, sebelum saudara di ruku'kan oleh } \\
\text { Allah. Orang tambah hari, tambah tahun, tambah usia tidak } \\
\text { semakin kokoh dan kuat. namun dengan sendirinya, saudara menjaga } \\
\text { akan bungkuk. Ayo podho-podho nglakoni rukuk dhisik } \\
\text { amprih kita jadi orang yang tansah syukur dihadapan Allah. }\end{array}$ & kepada Allah SWT. \\
\hline
\end{tabular}

Pada tabel 3 diatas, tindak tutur direktif dilakukan untuk mengajak para tamu undangan melakukan apa yang diucapkan oleh penutur. Ucapan tersebut dianggap sebagai tindak tutur direktif karena merupakan sebuah perintah yang berkaitan dengan agama. Dalam hal ini masuk dalam konteks pernikahan.

Tabel 4. Ekspresif

\begin{tabular}{|l|l|l|}
\hline No & \multicolumn{1}{|c|}{ Tindak Tutur } & \multicolumn{1}{|c|}{ Makna } \\
\hline 1 & $\begin{array}{l}\text { Alhamdulillah, saiki ora dadi wong liyo, ning dadi dulur } \\
\text { lan keluarga. } \\
\text { Alhamdulillah, sekarang tidak jadi orang lain melainkan } \\
\text { jadi saudara dan keluarga. }\end{array}$ & $\begin{array}{l}\text { Rasa syukur karena telah } \\
\text { menjadi bagian keluarga. }\end{array}$ \\
\hline 2 & $\begin{array}{l}\text { Mekaten anggen kito ngaturaken. Mbok bilih enten tutur } \\
\text { atau ucapan ingkang kirang dhumateng panjenengan } \\
\text { sedoyo, kulo nyuwun pangapunten ingkang kathah. }\end{array}$ & $\begin{array}{l}\text { Meminta maaf jika terdapat } \\
\text { kata-kata yang kurang } \\
\text { berkenan. }\end{array}$ \\
$\begin{array}{l}\text { Cukup sekian kami sampaikan. Jika terdapat perkataan } \\
\text { atau ucapan yang kurang kepada Anda sekalian, saya } \\
\text { mohon maaf sebesar-besarnya. }\end{array}$ & \\
\hline
\end{tabular}

Tindak tutur ekspresif dalam pidato tersebut mengandung ungkapan rasa syukur karena telah menjadi satu keluarga dan ungkapan maaf apabila terdapat kekurangan. Hal tersebut sesuai dengan kebiasaan masyarakat Jawa yang selalu meminta maaf walaupun tidak melakukan kesalahan.

\section{Tindak tutur yang terdapat dalam pidato yang disampaikan oleh pihak mempelai perempuan}

Dalam pidato yang disampaikan oleh pihak mempelai perempuan, ditemukan 
lima kategori tindak tutur yaitu, deklaratif, representatif, direktif, ekspresif dan komisif yang disajikan pada tabel-tabel berikut.

Tabel 5. Deklaratif

\begin{tabular}{|l|l|l|}
\hline No & \multicolumn{1}{|c|}{ Tindak Tutur } & \multicolumn{1}{|c|}{ Makna } \\
\hline 1 & $\begin{array}{l}\text { Mulai detik meniko, saat meniko, nak X kawulo tampi } \\
\text { ingkang asto kalih. }\end{array}$ & $\begin{array}{l}\text { Menerima mempelai laki-laki } \\
\text { dengan kedua tangan terbuka. } \\
\text { Mulai detik ini, saat ini, anak X kami terima dengan } \\
\text { tangan terbuka. }\end{array}$ \\
\hline
\end{tabular}

Jika pada pidato sebelumnya tindak tutur deklaratif disampaikan sebagai pernyataan untuk menyerahkan mempelai laki-laki kepada keluarga mempelai perempuan, maka tindak tutur deklaratif dalam pidato ini adalah membalas apa yang telah disampaikan oleh pihak keluarga laki-laki, yaitu menerima mempelai laki-laki. Sehingga, pada saat itu juga, mempelai laki-laki telah menjadi bagian dari keluarga mempelai perempuan.

Tabel 6. Representatif

\begin{tabular}{|l|l|l|}
\hline No & \multicolumn{1}{|c|}{ Tindak Tutur } & \multicolumn{1}{|c|}{ Makna } \\
\hline 1 & $\begin{array}{l}\text { Poro sesepuh dening sepuh, bapak-bapak, ibu-ibu, pendherek } \\
\text { temanten kakung saking tlatah Semanding, ingkang tansah } \\
\text { kawulo mulyaaken. } \\
\text { Yang kami tuakan, bapak-bapak, ibu-ibu, rombongan } \\
\text { pengantin laki-laki dari wilayah Semanding yang kami } \\
\text { mulyakan. }\end{array}$ & $\begin{array}{l}\text { Ucapan selamat dang } \\
\text { pada pihak keluarga } \\
\text { mempelai laki-laki. }\end{array}$ \\
\hline 2 & $\begin{array}{l}\text { Inggih meniko perjodohanipun Mas X kalihan Mbak Y } \\
\text { ingkang sampun kalaksana kolowau. }\end{array}$ & $\begin{array}{l}\text { Ucapan untuk } \\
\text { memberitahukan bahwa } \\
\text { pernikahan terlah } \\
\text { terlaksana. }\end{array}$ \\
$\begin{array}{l}\text { Allah SWT yang pada hari ini saya dan Anda sekalian bisa } \\
\text { hadir dan menyaksikan peristiwa yang sakral ini. Yaitu } \\
\text { perjodohan Mas Xdan Mbak Yyang telah terlaksana. }\end{array}$ & $\begin{array}{l}\text { Mugi-mugi benjang yaumul kiyamah, tansah pikantuk } \\
\text { syafaatipun. Aamiin } \\
\text { Semoga nanti saat hari kiamat, senantiasa mendapat } \\
\text { petunjuknya. Aamiin }\end{array}$ & $\begin{array}{l}\text { Harapan agar selalu } \\
\text { mendapat petunjuk dari } \\
\text { Allah SWT. }\end{array}$ \\
\hline
\end{tabular}

Tabel 7. Direktif

\begin{tabular}{|l|l|l|}
\hline No & \multicolumn{1}{|c|}{ Tindak Tutur } & \multicolumn{1}{|c|}{ Makna } \\
\hline 1 & $\begin{array}{l}\text { Keparuh matur, monggo kito sareng-sareng puji syukur wonten arsa } \\
\text { Allah SWT ... } \\
\text { Mari kita bersama-sama memanjatkan puja dan puji syukur pada } \\
\text { Allah SWT ... }\end{array}$ & $\begin{array}{l}\text { Perintah untuk } \\
\text { memanjatkan syukur } \\
\text { pada Allah SWT. }\end{array}$ \\
\hline
\end{tabular}




\begin{tabular}{|l|l|l|}
\hline 2 & $\begin{array}{l}\text { Sholawat lan salam, tetep kunjuk dhumateng junjungan kito nabi besar } \\
\text { SAW... } \\
\text { Sholawat dan salam selalu ditujukan kepada junjungan kita nabi besar } \\
\text { SAW ... }\end{array}$ & $\begin{array}{l}\text { Perintah untuk } \\
\text { memanjatkan syukur } \\
\text { pada Nabi SAW }\end{array}$ \\
\hline 3 & $\begin{array}{l}\text { Lan selajengipun, sak marinipun acara meniko, wonten acara ramah } \\
\text { tamah utawi foto bersama. } \\
\text { Dan selanjutnya, setelah acara ini, ada acara ramah tamah atau foto } \\
\text { bersama. }\end{array}$ & $\begin{array}{l}\text { Arahan untuk acara } \\
\text { selanjutnya, yaitu foto } \\
\text { bersama }\end{array}$ \\
\hline 4 & $\begin{array}{l}\text { Pramilo monggo acara meniko kito tutup kalih waosan doa. } \\
\text { Oleh karena itu, mari kita tutup acara ini dengan bacaan doa. }\end{array}$ & $\begin{array}{l}\text { Arahan untuk berdoa } \\
\text { bersama }\end{array}$ \\
\hline 5 & $\begin{array}{l}\text { Monggo kito dongakaken sareng-sareng, mugi anggenipun rumah } \\
\text { tangga Mbak Y kaliyan mas X meniko dadoso keluarga ingkang } \\
\text { sakinah, mawadah, warrohmah. }\end{array}$ & $\begin{array}{l}\text { Arahan untuk berdoa } \\
\text { bersama } \\
\text { Mari kita berdoa bersama-sama, semoga rumah tangga Mbak Y dan }\end{array}$ \\
\hline
\end{tabular}

Tindak tutur direktif dalam tabel ini berisi perintah-perintah yang disampaikan oleh perwakilan pihak mempelai perempuan kepada tamu undangan untuk melakukan sesuatu sesuai apa yang diucapkannya. Dalam hal ini adalah perintah untuk berdoa bersama dan menginformasikan bahwa setelah pidato selesai, para undangan bisa berfoto dengan kedua mempelai. Hal ini karena penutur berasal dari pihak mempelai perempuan yang mengadakan acara dan penyampaian pidato juga berada pada akhir acara. Sehingga penutur, sebagai tuan rumah, berhak memberikan perintah (lebih tepatnya arahan) kepada tamu undangan tentang acara pada saat itu.

Tabel 8. Ekspresif

\begin{tabular}{|l|l|l|}
\hline No & \multicolumn{1}{|c|}{ Tindak Tutur } & \multicolumn{1}{|c|}{ Makna } \\
\hline 1 & $\begin{array}{l}\text { Saklajengipun, atas nama Bapak E, maturnuwun sanget atas } \\
\text { kerawuhan panjenengan sami. } \\
\text { Selanjutnya, atas nama Bapak E, kami sangat berterima kasih } \\
\text { atas kedatangan Anda sekalian. }\end{array}$ & $\begin{array}{l}\text { Ucapan terima kasih } \\
\text { atas kehadiran keluarga } \\
\text { mempelai pria dan tamu } \\
\text { undangan. }\end{array}$ \\
\hline 2 & $\begin{array}{l}\text { Mbok bilih wonten kirang, Bapak E nyuwun pangapunten. } \\
\text { Jika terdapat kekurangan, Bapak E mohon maaf. }\end{array}$ & $\begin{array}{l}\text { Ucapan maaf dari keluarga } \\
\text { pihak perempuan. }\end{array}$ \\
\hline 3 & $\begin{array}{l}\text { Lan saking kawulo, mbok bilih wonten kiranganipun, kawulo } \\
\text { nggih nyuwun agunging samudro. } \\
\text { Dan dari kami, jika terdapat kekurangan, kami mohon maaf } \\
\text { sebesar-besarnya. }\end{array}$ & $\begin{array}{l}\text { Ucapan permohonan maaf } \\
\text { dari perwakilan pihak } \\
\text { mempelai perempuan } \\
\text { untuk mengakhiri pidato. }\end{array}$ \\
\hline
\end{tabular}

Dalam tabel di atas, tindak tutur ekspresif dilakukan sebagai bentuk ucapan terima kasih dan permintaan maaf. Ucapan terima kasih ini muncul di awal pidato sebagai rasa hormat kepada rombongan keluarga mempelai pria yang sudah hadir. 
Sedangkan, ucapan maaf disampaikan sebagai bentuk kerendahan hati si tuan rumah jika terdapat kekurangan, dalam hal ini pihak keluarga mempelai perempuan yang telah mempersiapkan acara.

Tabel 9. Komisif

\begin{tabular}{|c|l|l|}
\hline No & \multicolumn{1}{|c|}{ Tindak Tutur } & \multicolumn{1}{|c|}{ Makna } \\
\hline 1 & $\begin{array}{l}\text { Mugi-mugi kawulo sakeluarga Bapak E saget bimbing } \\
\text { kados dening putranipun tiyambak. }\end{array}$ & $\begin{array}{l}\text { Harapan untuk bisa } \\
\text { membimbing mempelai laki- } \\
\text { laki layaknya anak sendiri. } \\
\text { Semoga kami sekeluarga Bapak E bisa membimbing } \\
\text { seperti anak sendiri. }\end{array}$
\end{tabular}

Dalam tabel di atas, tindak tutur komisif terjadi ketika pihak perwakilan mempelai perempuan menyatakan bahwa mereka akan berusaha untuk membimbing mempelai laki-laki laiknya anak mereka di sini. Tuturan ini dikategorikan sebagai tindak tutur komisif karena terdapat tanggungjawab yang nantinya harus dilakukan oleh keluarga mempelai perempuan dalam membimbing mempelai laki-laki dalam keluarganya.

\section{KESIMPULAN}

Dari penelitian tersebut ditemukan bahwa terdapat lima kategori tindak tutur, yaitu deklaratif, representatif, ekspresif, direktif dan komisif dalam sebuah pidato prosesi pasrah tinampi. Jenis-jenis tindak tutur tersebut memiliki fungsi masingmasing berdasarkan konteksnya, yaitu pernikahan. Tindak tutur deklaratif dalam pidato ini digunakan untuk menyatakan penyerahan dan penerimaan mempelai pria dari kedua keluarga. Yangmana kalimat deklaratif tersebut mampu mengubah status mempelai laki-laki yang saat itu menjadi bagian dari keluarga mempelai perempuan. Kalimat representatif dalam pidato tersebut sebagian besar mengacu pada nasihatnasihat dan harapan dari pembaca pidato (yang merupakan perwakilan keluarga) yang ditujukan untuk kedua mempelai. Kalimat ekspresif dalam kedua pidato ini lebih banyak muncul sebagai bentuk rasa syukur, ucapan terima kasih dan permintaan maaf. Karena konteks acara ini merupakan acara pernikahan, maka ucapan terima kasih dan rasa syukur muncul sebagai bentuk kebahagiaan. Sedangkan, permintaan maaf, kedua keluarga tersebut memiliki latar belakang budaya yang sama, yaitu masyarakat Jawa. Sehingga, terdapat kebiasaan untuk meminta maaf jika terdapat kekurangan. Karena budaya yang berbeda, bahasa yang digunakan pada pidato tersebut sebagian besar menggunakan Bahasa Jawa Krama Madya. Kemudian, kalimat direktif dalam pidato tersebut digunakan oleh penutur untuk mengarahkan tamu undangan sesuai dengan apa yang dikatakannya. Yang terakhir, kalimat komisif dalam pidato ini menunjukkan adanya tanggungjawab penutur terhadap apa yang telah dikatakannya. 


\section{DAFTAR PUSTAKA}

Adams, Rebecca. Upacara Pernikahan di Jawa : Upacara-upacara, simbolisme, dan perbedaan daerah di Pulau Jawa.

Chaer, Abdul dan Agustina, Leonie. 2010. Sosiolinguistik. Jakarta: Rineka Cipta.

Djajasudarma, Fatimah. 1993. Metode Linguistik: Ancangan metode penelitian dan kajian. Jakarta: Refika Aditama

Saleh, K. Wantjik. 1976. Himpunan peraturan tentang perkawinan. Jakarta: Ghalia Indonesia.

Sibarani, T. 2008. Tindak tutur dalam upacara perkawinan masyarakat Batak Toba. Tesis. Universitas Sumatera Utara. Medan.

Sulistryowati, dkk. 2013. Perilaku tindak tutur ustad dalam pengajian: Kajian sosiopragmatik dengan endekatan "Bilingual". Jurnal Penelitian Humaniora, Vol. 14, No. 1, Februari 2013: 25-40

Surakhmad, Winarno. 1978. Dasar dan Tehnik Research, Pengantar Metodologi Ilmiah. Bandung: Tarsito.

Wardaugh, R. 2015. An Introduction to sociolinguistics. Wiley Blackwell. Oxford.

Wijana, I Dewa Putu. 1996. Dasar-dasar pragmatik. Yogyakarta: Andi Yogyakarta.

Yule, George. 1996. Pragmatics. Oxford University Press. Oxford. 